\title{
Identifying different methods for creating knowledge from lessons learned in project oriented organizations
}

\author{
Ahmad Norang ${ }^{a}$ and Seyed Mirahmad Nooshin ${ }^{b^{*}}$
}

${ }^{a}$ Associate Professor, Department of Industrial Engineering, Imam Hossein University, Tehran, Iran

${ }^{b} \mathrm{PhD}$ Student, Department of Industrial Engineering, Imam Hossein University, Tehran, Iran

\section{H R O N I C L E \\ A B S T R A C T}

Article history:

Received August 28, 2015

Received in revised format

November 28, 2015

Accepted December 6, 2015

Available online

December 6, 2015

Keywords:

Knowledge management

Knowledge creation

Project oriented organization

\begin{abstract}
Nowadays, the increase in competition has increased the relative importance of innovation for most firms and many managers believe a good innovation must be knowledge oriented. This paper has tried to determine different methods for creating knowledge in project oriented organizations. The study designs a questionnaire in Likert scale and distributes it among 32 experts who were well informed about different methods of knowledge creation and lessons learned. Cronbach alphas for all components of the survey were well above the desirable level. The study has detected 11 methods for knowledge creation and lessons learned. In terms of preliminary assessment, business transactions has received the highest impact while knowledge team has received the highest effect in terms of necessary assessment. The results of this survey have indicated that although there are several methods for detecting knowledge within organizations, in most cases, it is not easy to gain value added knowledge within an organization, quickly. The people who participated in our survey have indicated that organizational commitment, brainstorming, Delphi and storytelling also have played important role for creation of knowledge. The results have also shown that brainstorming, knowledge brokers, map knowledge and work experience were easier to use for knowledge creation and lessons learned compared with other forms of knowledge creation.
\end{abstract}

\section{Introduction}

The Adaption-Innovation theory is associated with differences in the thinking style of individuals, with specific association to creativity, problem solving and decision making (Carayannis \& Campbell, 2006). These issues will have specific association for managers, since they concentrate on the relationship between people and their often changing work environment, giving managers new insight on the personality characteristics of change in firms (Kirton, 1984; Dunn, 2003). Knowledge management techniques require to be chosen based on the purpose for which knowledge is "being

* Corresponding author. Tel: +98-912 1387426

E-mail address: mirahmad.nooshin@gmail.com (S. M. Nooshin) 
managed". Hoegl and Schulze (2005) proposed a work for encouraging knowledge creation in new product development (NPD) projects. They studied how some methods support knowledge creation during the development of new products by performing a survey of 356 responses of members of 94 NPD projects on the utilization of 14 knowledge management techniques. Garcia-Lorenzo et al. (2008) concentrated on the methods in which stories challenge the notions of knowledge, which are common in the "classical" scientific tradition. It also tried to concentrate on the function of stories in the collaborative, interpersonal and inter-organizational dynamics of the way knowledge is constructed in daily life. They concluded that a core characteristic of stories is associated with an increase in people's awareness.

Bartol and Srivastava (2002) investigated the role of monetary rewards in encouraging knowledge sharing in firms through four methods of knowledge sharing. They reported that the system of contributing knowledge to databases was the most amenable to rewards contingent on knowledge sharing behaviors because of possibility for the reward allocator to investigate the knowledge sharing behaviors. According to Bhatt (2000), organizational knowledge enables firms to bring innovative products/services continuously in the marketplace. Nevertheless, many have found it difficult to understand how firms create knowledge. Bhatt (2000) described how the sum of individual knowledge had not equated to organizational knowledge.

Bryant (2005) provided a study to investigate the relationship between peer mentoring and knowledge creation and sharing in a high-tech software firm. He reported that a peer mentor training course could possibly increase perceived levels of peer mentor knowledge and skills. Chan (2002) investigated the techniques that eight firms used to both monitor and improve the alignment and performance of their information sharing (IS) functions. They reported that aligning IS and business strategies could, possibly, improve IS performance. Chua (2002) investigated the effect of social interaction on the process of knowledge creation. He performed a cross-sectional study to determine the relationship between the level of social interaction and the quality of the knowledge created. The knowledge creation process, in their survey, was operationalized for the curriculum development process while the quality of the knowledge created was operationalized for the quality of the modules developed. He reported a positive correlation between the level of social interaction and the quality of the modules developed.

Garcia-Lorenzo et al. (2008) explored changes in the notion of knowledge. The study identified different genealogies in which previous limitations on the experiences to be included as knowledge had been extended. Then, study looked at experiences that link to the telling of stories, and explored the way they challenge and link to previous notions and extensions of knowledge in collaborative contexts. Hendriks (1999) developed a theoretical model to determine the variables involved in information and communication technology (ICT) in knowledge sharing. The study also illustrated the differential impacts of ICT on the motivation for knowledge sharing in various settings. Holsapple and Joshi (2002) characterized a set of elemental knowledge manipulation activities, which could be arranged in a different patterns within knowledge management (KM) episodes. The study also explained possible knowledge flows, which could happen among the activities. This descriptive framework was developed based on conceptual synthesis and a Delphi methodology involving an international panel of researchers and practitioners in the KM field.

\section{The proposed study}

This paper has tried to determine different methods for creating knowledge in project oriented organizations. The study designs a questionnaire in Likert scale and distributes it among 32 experts who were well informed about different methods of knowledge creation. Cronbach alphas for all components of the survey were well above the desirable level. The research community of this survey includes researchers and experts from one of research centers who were involved in project oriented organization and are also associated with knowledge management processes. The population of the 
survey includes 32 people, one woman and 31 men, and in this survey we consider all of these people as sample of our research study. Fig. 1 demonstrates personal characteristics of the participants.

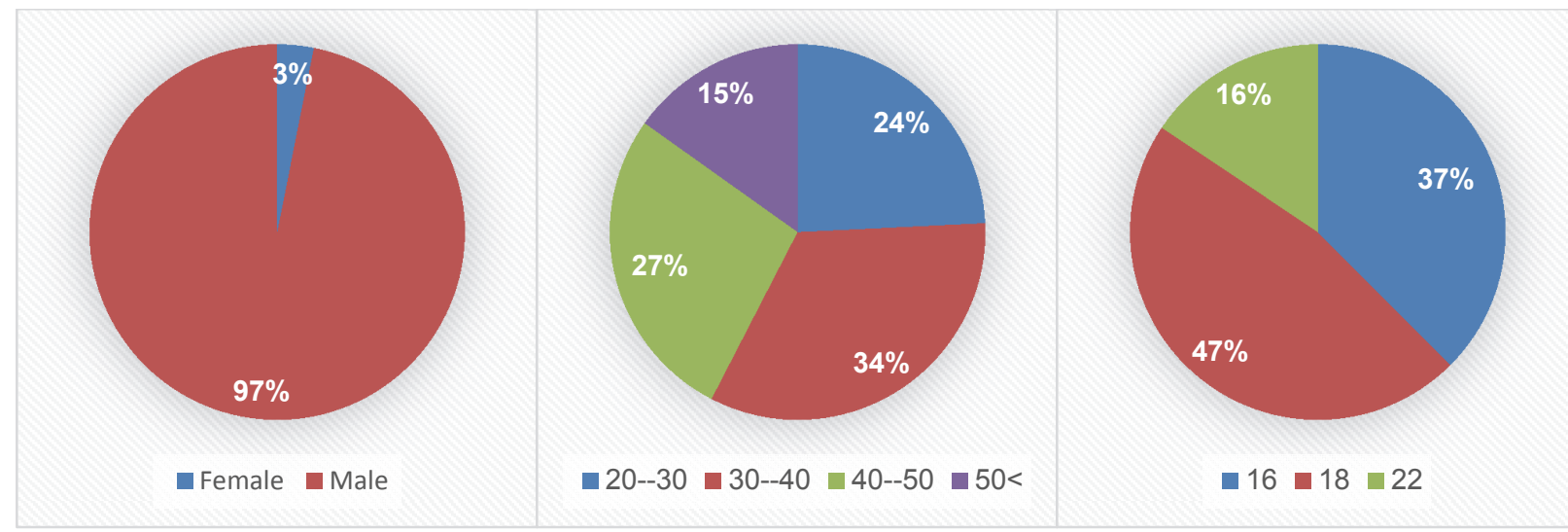

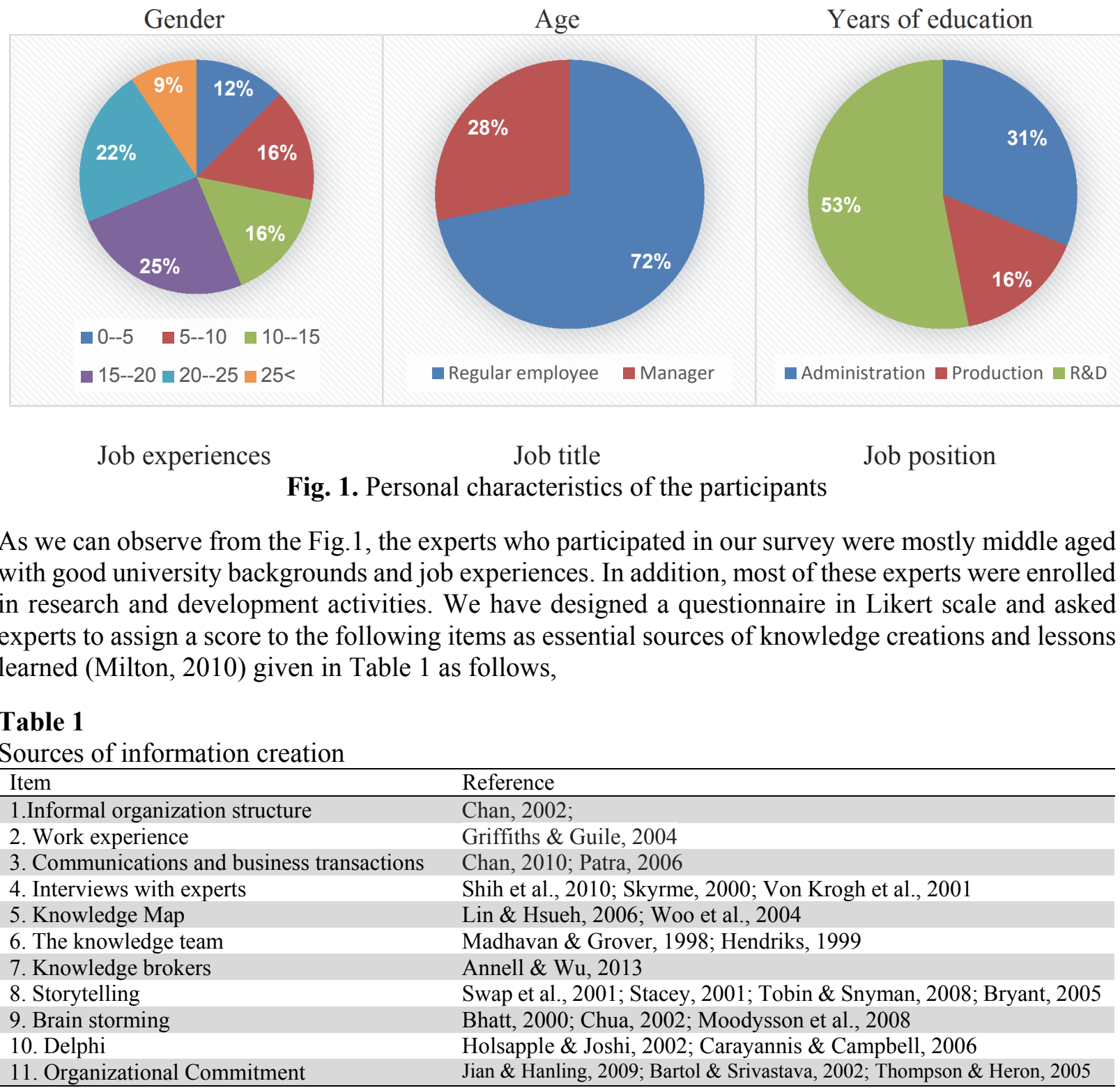


Table 2 shows the summary of the scores assigned to each of these questions. As we can observe from the table, experts were asked on what we have and what we need to create knowledge within organization. In addition, Fig. 2 shows the frequency of the scores given to each question.

Table 1

The summary the scores assigned to each question

\begin{tabular}{clcccc}
\hline \multirow{2}{*}{ Method } & \multicolumn{2}{c}{ Number of questions } & \multicolumn{2}{c}{ Scores collected } \\
\cline { 3 - 6 } & $\begin{array}{c}\text { Preliminary } \\
\text { assessment }\end{array}$ & $\begin{array}{c}\text { Necessary } \\
\text { infrastructures }\end{array}$ & $\begin{array}{c}\text { Preliminary } \\
\text { assessment }\end{array}$ & $\begin{array}{c}\text { Necessary } \\
\text { infrastructures }\end{array}$ \\
\hline 1 & Informal organization structure & 3 & 4 & 86 & 91.25 \\
2 & Work experience & 3 & 4 & 78.5 & 98.5 \\
3 & Business transaction & 3 & 3 & 137.3 & 97 \\
4 & Interviews with experts & 3 & 7 & 95 & 86.7 \\
5 & Knowledge map & 3 & 4 & 87 & 99.5 \\
6 & Knowledge team & 3 & 2 & 90 & 123 \\
7 & Knowledge dealers & 3 & 4 & 75.7 & 100.5 \\
8 & Story telling & 3 & 4 & 91.7 & 97.25 \\
9 & Brain storming & 3 & 4 & 102.3 & 102.5 \\
10 & Delphi & 3 & 3 & 96.3 & 74.5 \\
11 & Organizational commitment & 3 & 3 & 103.7 & 95 \\
\hline
\end{tabular}

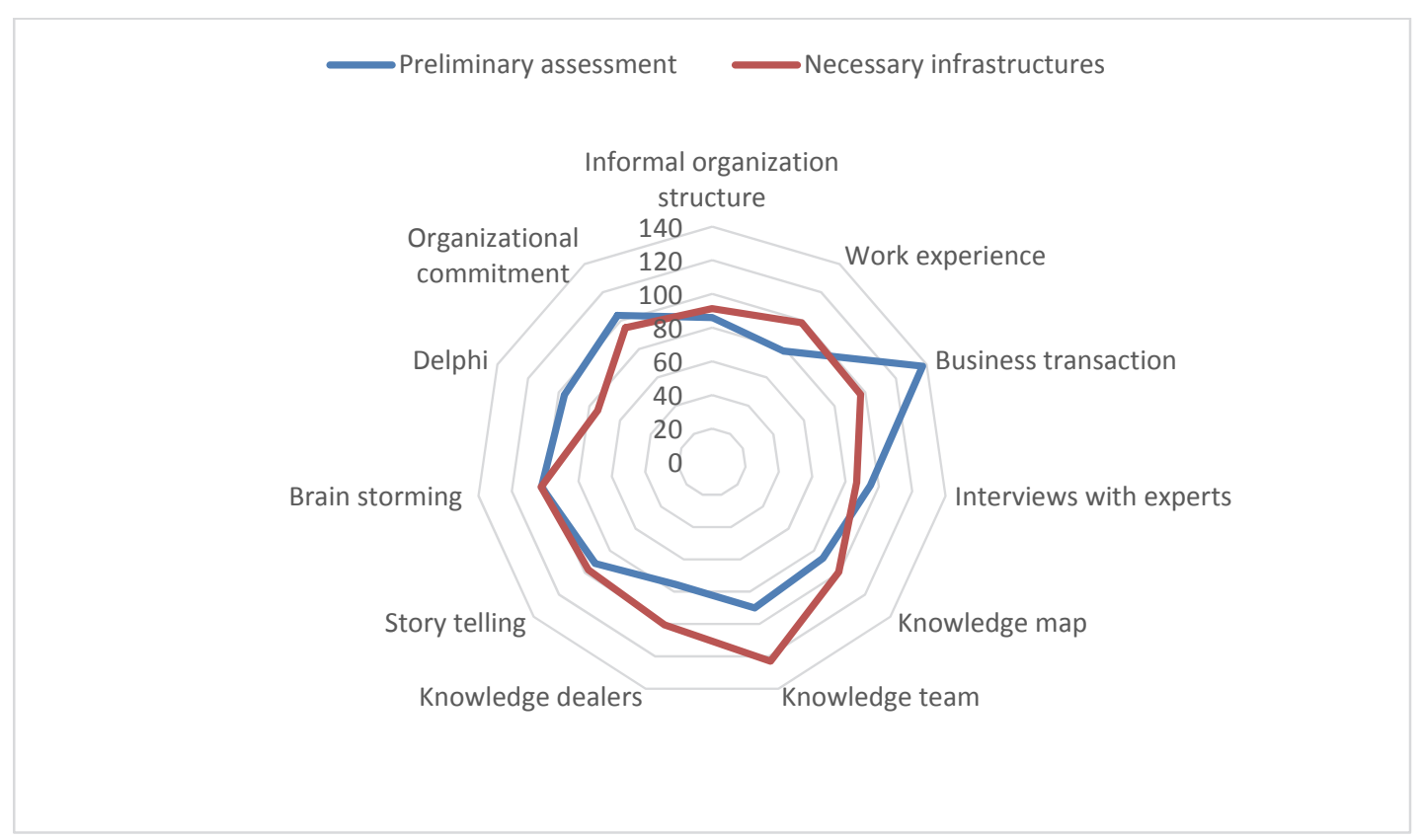

Fig. 2. The frequency of the scores assigned to preliminary and necessary assessment for knowledge creation and lessons learned

\section{Discussion and conclusion}

This paper has tried to determine different methods for creating knowledge. According to the results of Fig. 2, most of the items have maintained similar scores, which order them in the same priority. In terms of preliminary assessment, business transactions has received the highest impact while knowledge team has received the highest effect in terms of necessary assessment. The results of this survey have indicated that although there are several methods for detecting knowledge within organization, in most cases, it is not easy to gain value added knowledge within an organization, quickly. The people who participated in our survey have indicated that organizational commitment, brainstorming, Delphi and storytelling also have played important role for creation of knowledge and lessons learned. The research results have also shown that brainstorming, knowledge brokers, map 
knowledge and work experience were easier to use for knowledge creation and lessons learned compared with other forms of knowledge creation.

\section{Acknowledgement}

The authors would like to thank the anonymous referees for constructive comments on earlier version of this paper.

\section{References}

Annell, J., \& Wu, C. (2013). Knowledge management in global teams: A case study at Volvo IT in Sweden and China. Master of Science Thesis in Production Engineering, CHALMERS UNIVERSITY OF TECHNOLOGY.

Bartol, K. M., \& Srivastava, A. (2002). Encouraging knowledge sharing: The role of organizational reward systems. Journal of Leadership \& Organizational Studies, 9(1), 64-76.

Bhatt, G. D. (2000). Information dynamics, learning and knowledge creation in organizations. The Learning Organization, 7(2), 89-99.

Bryant, S. E. (2005). The impact of peer mentoring on organizational knowledge creation and sharing an empirical study in a software firm. Group \& Organization Management, 30(3), 319-338.

Carayannis, E. G., \& Campbell, D. F. (2006). Knowledge creation, diffusion, and use in innovation networks and knowledge clusters: a comparative systems approach across the United States, Europe, and Asia. Greenwood Publishing Group.

Chan, Y. E. (2002). Why haven't we mastered alignment? The importance of the informal organization structure. MIS Quarterly executive, 1(2), 97-112.

Chan, J. O. (2010). E-business enabled ERP II architecture. Communications of the IIMA, 10(1), 44.

Chua, A. (2002). The influence of social interaction on knowledge creation. Journal of Intellectual Capital, 3(4), 375-392.

Dunn, W. N. (2003). Public policy analysis: An introduction.

Garcia-Lorenzo, L., Nolas, S. M., \& de Zeeuw, G. (2008). Telling stories and the practice of collaboration. International Journal of Sociology and Social Policy, 28(1/2), 9-19.

Griffiths, T., \& Guile, D. (2004). Learning through work experience for the knowledge economy: Issues for educational research and policy.

Hendriks, P. (1999). Why share knowledge? The influence of ICT on the motivation for knowledge sharing. Knowledge and Process Management, 6(2), 91-100.

Hoegl, M., \& Schulze, A. (2005). How to support knowledge creation in new product development: An investigation of knowledge management Methods.European Management Journal, 23(3), 263273.

Holsapple, C. W., \& Joshi, K. D. (2002). Knowledge manipulation activities: results of a Delphi study. Information \& Management, 39(6), 477-490.

Jian, Y., \& Hanling, L. (2009, September). Psychological capital as mediator in relationship among organizational socialization, knowledge integration and sharing. In Management and Service Science, 2009. MASS'09. International Conference on (pp. 1-4). IEEE.

Kirton, M. J. (1984). Adaptors and innovators-Why new initiatives get blocked.Long Range Planning, 17(2), 137-143.

Lin, F. R., \& Hsueh, C. M. (2006). Knowledge map creation and maintenance for virtual communities of practice. Information Processing \& Management, 42(2), 551-568.

Madhavan, R., \& Grover, R. (1998). From embedded knowledge to embodied knowledge: new product development as knowledge management. The Journal of marketing, 62(4), 1-12.

Milton, N. (2010). The lessons learned handbook: Practical approaches to learning from experience. Oxford: Chandos Publishing.

Moodysson, J., Coenen, L., \& Asheim, B. (2008). Explaining spatial patterns of innovation: analytical and synthetic modes of knowledge creation in the Medicon Valley life-science cluster. Environment and planning. A, 40(5), 1040. 
Patra, C. (2006). Developing a digital library on ceramics. The Electronic Library, 24(4), 453-469.

Shih, K. H., Chang, C. J., \& Lin, B. (2010). Assessing knowledge creation and intellectual capital in banking industry. Journal of intellectual capital, 11(1), 74-89.

Skyrme, D. J. (2000). Developing a knowledge strategy: from management to leadership. Knowledge management: Classic and contemporary works, 61-84.

Swap, W., Leonard, D., \& Mimi Shields, L. A. (2001). Using mentoring and storytelling to transfer knowledge in the workplace. Journal of management information systems, 18(1), 95-114.

Stacey, R. D. (2001). Complex responsive processes in organizations: Learning and knowledge creation. Psychology Press.

Thompson, M., \& Heron, P. (2005). The difference a manager can make: organizational justice and knowledge worker commitment. The International Journal of Human Resource Management, 16(3), 383-404.

Tobin, P. K., \& Snyman, R. (2008, March). Once upon a time in Africa: a case study of storytelling for knowledge sharing. In Aslib Proceedings (Vol. 60, No. 2, pp. 130-142). Emerald Group Publishing Limited.

Von Krogh, G., Nonaka, I., \& Aben, M. (2001). Making the most of your company's knowledge: a strategic framework. Long range planning, 34(4), 421-439.

Woo, J. H., Clayton, M. J., Johnson, R. E., Flores, B. E., \& Ellis, C. (2004). Dynamic Knowledge Map: reusing experts' tacit knowledge in the AEC industry. Automation in construction, 13(2), 203-207.

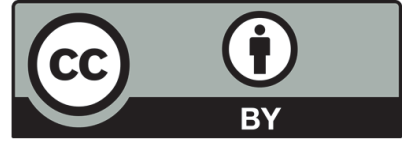

(C) 2016 by the authors; licensee Growing Science, Canada. This is an open access article distributed under the terms and conditions of the Creative Commons Attribution (CC-BY) license (http://creativecommons.org/licenses/by/4.0/). 